\title{
Motivation toward English Language Learning among Iraqi University Students
}

\author{
Saleh Jebrael Saleh', Shahen Jamal Majeed ${ }^{2}$ \\ ${ }^{1}$ Center of Scientific Research Development, Nawroz University, Kurdistan Region, Duhok, Iraq. \\ ${ }^{2}$ College of Education and Languages/ English Department, Lebanese French University, Iraq
}

\begin{tabular}{|c|c|}
\hline Article Info & Abstract \\
\hline $\begin{array}{l}\text { Article history: } \\
\text { Received: 04 June } 2021 \\
\text { Revised: 07 July } 2021 \\
\text { Accepted: 09 July } 2021\end{array}$ & $\begin{array}{l}\text { Purpose: This study aimed to examine motivation toward learning the } \\
\text { English Language among learners from different universities in Iraq. The } \\
\text { study focused on identifying the type of, instrumental and integrative, and } \\
\text { also the activities that learners prefer to use in the classroom. } \\
\text { Methodology/Approach/Design: The studv applied both qualitative and }\end{array}$ \\
\hline $\begin{array}{l}\text { Keywords: } \\
\text { Learning English, Motivation, } \\
\text { Integrative Motivation, } \\
\text { Instrumental Motivation, } \\
\text { Learning Activities. }\end{array}$ & $\begin{array}{l}\text { quantitative design. The instruments used in the study included } \\
\text { questionnaires and semi-structured interviews. A sample of } 200 \text { participants } \\
\text { were engaged in an online survey and filled the questionnaire questions. An } \\
\text { interview through zoom was also conducted with the selected group of } \\
\text { learners. } \\
\text { Results: The findings of the study revealed that learners were motivated }\end{array}$ \\
\hline $\begin{array}{l}\text { Paper Type : } \\
\text { Research Article }\end{array}$ & $\begin{array}{l}\text { more instrumentally as compared to integratively. It was also evident that } \\
\text { the students were interested in different learning activities. } \\
\text { Practical Implication: This study will have a greater contribution to the }\end{array}$ \\
\hline $\begin{array}{l}\text { Corresponding Author: } \\
\text { Saleh Jebrael Saleh } \\
\text { Email: } \\
\text { saleh.saleh@ nawroz.edu.krd }\end{array}$ & $\begin{array}{l}\text { pedagogy of English language learning. The findings of the study might be } \\
\text { used by curriculum developers to make changes and implement the best } \\
\text { techniques of teaching English in the Iraqi EFL curriculum. } \\
\text { Originality/Value: The results of this study may make the university teachers } \\
\text { and students aware of the significance of motivation in enhancing the English } \\
\text { learning process. Also, the findings may make university teachers more } \\
\text { creative in developing interactive learning activities that will be suitable for } \\
\text { students. }\end{array}$ \\
\hline
\end{tabular}

\section{Introduction}

In the last ten years, Iraq has broadly been linked with the outside world through business and other diplomatic activities. Students from Iraq have joined various learning institutions globally for the sake of learning English (Bao et al., 2012). Motivation plays a major role in the process of learning a foreign language as it encourages and enhances the language learners to use the English language (Gardner, 2007). In line with the works of Ellis (1994), motivation is critical in the process of learning a new language. Similarly, Binalet and Guerra (2014) did an investigation on the essence of motivation and discovered that it plays a major role in the process of learning a new language. Motivation together with other related factors, such as personality and age, will always affect either directly or indirectly the success of the acquisition of a new language. According to Mohd Redzuan Anak Buda, \& Abdullah (2014), motivation is a key element that influences the process of learning. The works of Horwitz (1990) described motivation as the feeling of learners to a particular language and the norms and culture of the 
people who use the language. Acquisition of foreign language by learners is very crucial as it enables them to communicate globally with friends. Learners will always find it hard to learn a foreign language if they are not motivated to do so (Gardner, 2007).

Just like many other Arab countries, students from Iraq have faced a lot of difficulties in using English to communicate with foreigners and also with their peers. Even though much effort has been put into the curriculum system of Iraq to make sure learners are equipped with English skills, still most of the learners are not in a position to use English effectively in communication. Some of the learners who try to use English find themselves using wrong tenses and vocabulary sometimes Bao et al. (2012). This could be attributed to their lower levels of motivation. In line with the works of Albodakh and Cinkara (2017), many of the students from Iraq believe that it is difficult to master the English language due to their inadequate motivation. It is difficult to attain learning activities without students being motivated. According to Abdulrasoul (2012), teaching materials should be selected based on the students' motivation. Thereby, this study focused on the identification of learners' motivation toward learning English and also investigate the activities they preferred to use in the learning process.

\section{Literature Review}

The two types of motivation which include integrative and instrumental were first discovered by Gardner and Lambert (1959). According to Redzuan et al. (2014), integrative motivation is very crucial to individuals who want to learn the English language so that they can be capable of integrating into the society in which English is used as the first language. Likewise, Carreira (2005) states that instrumental motivation is majorly used in learning a new language by individuals who want their salaries to be increased or get a new job. Based on most literature reviews on motivation, it is evident that most target language learners lie in the instrumental motivation category (Al-Tamimi \& Shuib; Wong, 2011).

Related theories suggest that motivation is linked with the drive and arousal concepts. Thereafter, psychology theories were developed to prevent the restriction of the behaviourist theories concerning motivation and learning. These theories revealed that motivation is a process that is usually influenced by individuals' believes and thoughts. The researcher relied on a cognitive perspective when dealing with motivation. In line with Gardner (1985), there are four elements of motivation: they include a goal, behavioural attempts, the focus to achieve the goal, and an appropriate attitude toward the process. According to Abdulrasoul (2012), social psychology plays a major role in pushing and motivating learners in the process of acquisition of a second language. Lambert (1993) came up with a social psychological model where it focused on some cognitive factors which included attitudes, language aptitudes, motivation, and intelligence.

Many researchers have come up with different definitions of motivation. In line with the works of Gardner (1985), learning language motivation encompasses the extent to which people make efforts to acquire a new language because of the desire to do so and the contentment encountered in the process. According to Brown (1994), motivation involves 
people's choices as to what approach they will use based on the goals and the level of willingness they will portray during the process. Similarly, based on the works of Kumar (2005), motivation came from the Latin word 'mover' which means to put move or put into action. Thereby he defined motivation as the process of putting students into psychological action whereby they can attain their desires (Abdulrasoul, 2012).

All university students consider learning the English language a very significant activity. For the purposes of making learners more motivated in the process of learning the English language, it is important to put into consideration the classroom activities that are suitable for them. The selection of appropriate classroom activities will make learners more motivated in the process of learning a new language. According to Qin (2012), it was evident that students loved activities like doing listening activities and reciting tests whereas instructors preferred communicative activities.

Many studies concerning Iraqi EFL motivation have been conducted by many researchers previously. These studies focused on various related issues such as types of motivation, the learning instruments in the acquisition of target language, and the purpose of motivation in target language learning. Bao et al. (2012) researched the factors that affected the second language learners from Iraq who studied in Australia. The findings revealed that the two categories of motivation that are instrumental and integrative were positively associated. The two types of motivation were the major reason that influenced the learners to study the English language. It was also evident from their studies that women were less motivated to learn English.

Abdulrasoul (2012) conducted a study to investigate how students from Iraq were motivated to join English departments. The results of his findings revealed that the learners were motivated more integratively than instrumentally.

Similarly, Albodakh \& Cinkara (2017) conducted a study to investigate the association of motivation of EFL learners from Iraq and the vocabulary size. Their study made use of a questionnaire and vocabulary size test to gather data from the participants. It was evident from their study that female learners were more motivated for intrinsic and extrinsic motivation. Based on the association of student motivation and vocabulary size, the findings revealed that there was no positive relation.

Similarly, Hussein and Al Bajalani (2019) investigated the role of motivation in supporting autonomy within English foreign language university students in Iraq. The study employed a mixed-method approach to gather data from the participants. The findings revealed that motivation plays a major role in the creation of autonomy of EFL learners.

The present study is focused mainly on instrumental and integrative motivation. In Iraq, the previous studies seem to have ignored these two types of motivation. Some studies have just investigated one type of motivation. Hence, this study investigates whether these two types of motivation have an impact on students' attitudes towards English language learning. The study is concerned with tertiary level students. 


\section{Methodology and Procedures}

\section{Participants}

The sample of the survey was drawn from students from different universities in Iraq who were invited to participate in an online survey. The participants included 200 students from different universities in Iraq. The students were purposively selected by the researcher based on his suitability in the gathering of data concerning the objectives that were developed.

Table 1: Participants information

\begin{tabular}{|l|l|}
\hline University & Number \\
\hline University of Halabia & 35 \\
\hline University of Mosul & 48 \\
\hline University of Duhok & 53 \\
\hline Iraqi University & 22 \\
\hline Alsalam University College & 42 \\
\hline Total & $\mathbf{2 0 0}$ \\
\hline
\end{tabular}

Source: Authors

\section{Instrument}

The researcher made use of two data collection instruments which included questionnaires and semi-structured interviews. The questionnaire was divided into four parts where the first part focused on the background information of learners, the second part looked at integrative motivation, instrumental motivation dominated the third part and lastly, the fourth section looked at the preferred learning activities by students. The elements of the questionnaire were based on Wimolmas's Survey of Motivation (2013). The questions of the questionnaires were rated by application of a five-point Likert scale that ranged from 'Highly Agree' to 'Highly Disagree'. The validity of the questionnaire was obtained by sending the questionnaire items to three experts where they confirmed that they were suitable and reliable.

\section{Research Procedures}

A sample of 200 learners fully completed the questionnaire questions and submitted them. The researcher made a confirmation that all the items were completely filled as expected. The participants were provided with a small guideline concerning the purpose of the study and some instructions on how to answer the questionnaire items. However, the researcher did not disclose to the participants concerning the types of motivation that were present in the questionnaire. Similarly, the researcher identified a section of the learners where he interviewed them via zoom. Before interviewing the selected students, he gave them a brief explanation of the integrative and instrumental motivation.

\section{Results and Discussion}

This part is categorized into two subsections where the first section presents the analysis of data from the questionnaires and the second part presents the data analysis from the semistructured interview. 


\section{Data obtained from the Questionnaire}

Data obtained from the questionnaire was analysed by the 'Statistical Package for the Social Sciences' (SPSS). A descriptive analysis was employed to obtain data concerning the motivation types and preferred activities.

Table 2: Descriptive Analysis of Instrumental Motivation

\begin{tabular}{|l|l|l|l|l|l|l|}
\hline No & Items & $\mathbf{N}$ & Minimum & Maximum & Mean & $\begin{array}{l}\text { Std. } \\
\text { Deviation }\end{array}$ \\
\hline 1 & $\begin{array}{l}\text { I use English to do my assignments and exams } \\
\text { only }\end{array}$ & 200 & 1 & 5 & 4.11 & 1.07 \\
\hline 2 & $\begin{array}{l}\text { I read English materials that relate to my } \\
\text { assignment only. }\end{array}$ & 200 & 1 & 5 & 2.72 & 1.04 \\
\hline 3 & $\begin{array}{l}\text { I usually copy directly sentences from books } \\
\text { even though I don't get what they mean. }\end{array}$ & 200 & 1 & 5 & 4.44 & 0.82 \\
\hline 4 & $\begin{array}{l}\text { I learn English for the sake of passing my } \\
\text { exams and get good jobs after education. }\end{array}$ & 200 & 1 & 5 & 3.07 & 1.16 \\
\hline 5 & $\begin{array}{l}\text { I learn English because it is a necessity for } \\
\text { traveling abroad. }\end{array}$ & 200 & 1 & 5 & 2.91 & 1.17 \\
\hline 6 & $\begin{array}{l}\text { I learn English to obtain a good job in the } \\
\text { future. }\end{array}$ & 200 & 1 & 5 & 2.62 & 1.15 \\
\hline 7 & $\begin{array}{l}\text { I learn English because it will make me be } \\
\text { successful and achieve more in life. }\end{array}$ & 200 & 1 & 5 & 2.57 & 1.38 \\
\hline 8 & $\begin{array}{l}\text { I learn English for the sake of obtaining } \\
\text { respect from peers and other people. }\end{array}$ & 200 & 1 & 5 & 3.55 & 1.24 \\
\hline 9 & $\begin{array}{l}\text { I learn English so as I can look more } \\
\text { knowledgeable. }\end{array}$ & 200 & 1 & 5 & 4.26 & 1.37 \\
\hline & Total & $\mathbf{2 0 0}$ & $\mathbf{1}$ & $\mathbf{5}$ & $\mathbf{3 0 . 2 5}$ & $\mathbf{1 0 . 4}$ \\
\hline
\end{tabular}

Source: Authors

Table 2 above displays results for a descriptive analysis for instrumental motivation. Most elements based on instrumental motivation attained a high mean scores. From the results, the majority of the learners agreed that they only use English to do their exams and assignments. Similarly, the majority of the learners reported that they only read English materials that were related to their studies. It was also evident that most of the learners only read English for the sake of passing their exams and getting good jobs. Generally, the findings revealed that most students had a positive response to elements that were related to instrumental motivation. The mean scores in the above table ranged from $(M=4.44$ to $\mathrm{M}=2.57)$ respectively.

Table 3: Descriptive Analysis of Integrative Motivation

\begin{tabular}{|l|l|l|l|l|l|l|}
\hline No & Items & $\mathbf{N}$ & Minimum & Maximum & Mean & $\begin{array}{l}\text { Std. } \\
\text { Deviation }\end{array}$ \\
\hline 1 & $\begin{array}{l}\text { I learn English so as I can be capable of } \\
\text { understanding English movies and books. }\end{array}$ & 200 & 1 & 5 & 1.49 & 0.96 \\
\hline 2 & $\begin{array}{l}\text { I learn English because it will help me to } \\
\text { understand the way of life of foreigners. }\end{array}$ & 200 & 1 & 5 & 1.45 & 0.74 \\
\hline 3 & $\begin{array}{l}\text { I learn English because it will help me to be } \\
\text { in a position to discuss exciting topics } \\
\text { globally. }\end{array}$ & 200 & 1 & 5 & 2.61 & 0.97 \\
\hline 4 & $\begin{array}{l}\text { I learn English because I have a passion for } \\
\text { joining activities that are organized by } \\
\text { international institutions. }\end{array}$ & 200 & 1 & 5 & 2.12 & 0.93 \\
\hline 5 & $\begin{array}{l}\text { I learn English because it enables me to } \\
\text { transfer my knowledge to foreigners like }\end{array}$ & 200 & 1 & 5 & 2.05 & 1.11 \\
\hline
\end{tabular}




\begin{tabular}{|l|l|l|l|l|l|l|}
\hline & giving tourists directions. & & & & & \\
\hline 6 & $\begin{array}{l}\text { I learn English because it enables me to be } \\
\text { friendly like English foreign speakers. }\end{array}$ & 200 & 1 & 5 & 1.93 & 0.94 \\
\hline 7 & $\begin{array}{l}\text { I learn English because it enables me to gain } \\
\text { the accent of native speakers and act like } \\
\text { foreign speakers. }\end{array}$ & 200 & 1 & 5 & 2.97 & 1.38 \\
\hline 8 & $\begin{array}{l}\text { I learn English because I am interested in the } \\
\text { beliefs and norms of people from different } \\
\text { parts of the world. }\end{array}$ & 200 & 1 & 5 & 2.23 & 1.35 \\
\hline 9 & $\begin{array}{l}\text { I learn English because I have a passion for } \\
\text { getting to know people from other cultures. }\end{array}$ & 200 & 1 & 5 & 3.05 & 1.49 \\
\hline 10 & $\begin{array}{l}\text { I learn the English language so as I can be } \\
\text { perfect and have a better understanding of } \\
\text { the language. }\end{array}$ & 200 & 1 & 5 & 3.02 & 1.31 \\
\hline Total & $\mathbf{2 0 0}$ & $\mathbf{1}$ & $\mathbf{5}$ & $\mathbf{2 2 . 9 2}$ & $\mathbf{1 1 . 1 8}$ \\
\hline
\end{tabular}

Source: Authors

Table 3 depicts a descriptive analysis for integrative motivation. It was evident from the learners' responses that most items concerning integrative motivation had a lower mean score. The majority of the learners disagreed with the fact that they learn English to know native English. Similarly, the majority of the learners disagreed with the idea that they learn English so that they can discuss interesting topics globally. Also, it was evident that the majority of the participants disagreed with the fact that they learned the English language to know people from other cultures. In addition, a large percentage of the learners highly disagreed with the idea that they learned the English language because they are interested in other peoples' cultures around the world. The mean scores in the above table ranged from (M $=3.05$ to $\mathrm{M}=1.45$ ) respectively.

Table 4: Descriptive Statistics of Preferred Activities

\begin{tabular}{|l|l|l|l|l|l|l|}
\hline No & Items & $\mathbf{N}$ & Minimum & Maximum & Mean & $\begin{array}{l}\text { Std. } \\
\text { Deviation }\end{array}$ \\
\hline 1 & $\begin{array}{l}\text { I like to practice speaking English with my } \\
\text { peers in class so that I can learn the language. }\end{array}$ & 200 & 1 & 5 & 1.35 & 0.77 \\
\hline 2 & $\begin{array}{l}\text { I like listening and copying notes from the } \\
\text { board so that I can learn English. }\end{array}$ & 200 & 1 & 5 & 5.19 & 2.22 \\
\hline 3 & $\begin{array}{l}\text { I like playing games in English in the process } \\
\text { of learning English }\end{array}$ & 200 & 1 & 5 & 2.81 & 1.21 \\
\hline 4 & $\begin{array}{l}\text { I like reading a lot of English materials so as } \\
\text { to learn English. }\end{array}$ & 200 & 1 & 5 & 4.33 & 2.84 \\
\hline 5 & $\begin{array}{l}\text { I like doing role-plays and dramas in the } \\
\text { process of learning English. }\end{array}$ & 200 & 1 & 5 & 1.38 & 0.82 \\
\hline 6 & $\begin{array}{l}\text { To learn English, I like summarizing what I } \\
\text { have learned in class. }\end{array}$ & 200 & 1 & 5 & 2.91 & 1.17 \\
\hline & Total & $\mathbf{2 0 0}$ & $\mathbf{1}$ & $\mathbf{5}$ & $\mathbf{1 7 . 9 7}$ & $\mathbf{9 . 0 3}$ \\
\hline
\end{tabular}

Source: Authors

Table four displays descriptive statistics for the activities that students preferred based on the questionnaire. It was evident that different students preferred different activities. From the table, it can be seen that most learners preferred listening and copying notes from the board $(M=5.19)$. However, the majority of the learners highly disagreed with the idea that they liked to speak English with their friends in class $(\mathrm{M}=1.35)$. Generally, the findings displayed from the table reveal that students preferred all other activities differently. 


\section{Data obtained from the Semi-Structured Interview}

Q1. Students were asked their views concerning if motivation is significant in learning a foreign language and why they thought so.

All the respondents agreed that motivation is significant in the process of learning a foreign language. This can be shown in the responses they gave below.

A portion of the learners stated 'just like any other language such as mother tongue, for English language, it is very important to be motivated so as you can learn, understand and master the principles of the language and use it efficiently. Because currently, the English language is very crucial globally, it is very important for us to remain motivated so that we can continue being updated with the upgrade in the English language and its principles'

Some learners claimed "Yes, of course, if someone has a desire to learn a new thing and is derived by his personal motivation, then it is automatic he/she will acquire the target language he/she is aspiring to learn"

Others claimed that "I believe motivation plays a major role in English language learning. However, the type of motivation varies from one person to another"

Q2. The learners were asked to give their opinion on the type of motivation (instrumental or integrative) that they thought had a great impact on learning a foreign language (English) and why they thought so.

Based on this question, the responses from the learners were not consistent. Some students claimed that integrative motivation was more important in learning English. A portion of the students was not in a position to decide which type of motivation was more important and lastly some claimed that the type of motivation could depend on the circumstance as to whether the learners are acquiring the English language for the sake of getting a job or integrating into a foreign culture. The following are some of the responses from the participants:

Some students stated "in my opinion, using English for the sake of doing assignments or getting a job could not lead to mastery of English in reality. It will show that the motivation is fake or temporary because learning of English will only be triggered by a particular purpose of which after achieving the purposes could lead to loss of interest. Learning English so that you can be capable of integrating with other communities is very significant. Integrative motivation will enable target language learners to be more perfect English speakers and be in a position to interact and communicate with people from foreign countries and get to know their culture and traditions. It makes the target language learners gain more interest and do more research to explore and make further learning of the language".

A small portion of the students claimed "Am not in a position to decide, but what I can say generally is that learning the English language is very important" 
Others stated that 'circumstance is the key determinant of learning the English language. At times we learn English for the sake of getting a job. Also, we learn English so that we can integrate perfectly with the native community. In my opinion, I use English not only for doing my assignment but also to be in a position to talk fluently with foreigners.

Q3. The students were also asked to give their opinion on whether learners who are integratively motivated or instrumentally motivated are the ones who use English correctly and the reasons they thought so.

This question required the respondents to decide whether integratively or instrumentally learners are the ones who use English correctly. A large portion of the respondents agreed with the fact that integratively motivated learner uses English correctly. On the other hand, a small portion of the learners disagreed with this idea and claimed that learners who were instrumentally motivated used the English language perfectly. Below are some of the responses from the learners.

In my perspective, a person who has a desire to master a language will always do it perfectly and make sure he understands the norms and beliefs of people of the target language. He will always want to keep in touch with foreign speakers by watching foreign films. This will increase his love and passion for the language to be learned and thereby make an extra attempt of doing more research and look for more challenging vocabularies.

A large number of the respondents stated 'people who learn English to achieve a specific goal will never continue to have the interest of learning the language after achieving the goal.'

Others stated that integratively motivated learners use English perfectly. They gave reasons that it is because these learners acquire the English skills by listening to songs, chatting with foreigners, or watching foreign films. They went further and revealed that in their class they are less motivated because they only use the English language for grammar.

A small portion of the respondents stated "learners who are instrumentally motivated use English perfectly because it is a key requirement for his work and thereby he has to master it.

Q4. The respondents were to give their reasons and views on if they thought the selected activities by the teacher were significant in identifying or improving the type of motivation of learners in learning English.

The researcher used this question to determine if the participants agree with the facts that the activities are significant in identifying or improving the type of motivation of learners and also if the students had any activities they loved most. All the participants agreed with this idea. However, none of the participants identified any activity he loved. This could be illustrated in their responses below. 
A portion of the respondents stated "Yes, the activities play a major role. But most of our instructors don't put this into their consideration. Most of our teachers only focus on one or two activities. They never make attempts of expanding the activities.

Some students stated "Yes, of course, we believe both activities outside the classroom and inside the classroom are crucial. We believe the activities play a major role in enhancing the kind of motivation in English language learning.

Others stated "Yes, of course, the activities can improve the motivation of learners to learning English.

\section{Discussion}

Based on data analysis, it is evident that the majority of the learners were motivated more instrumentally than integratively. This finding goes against the works of Bao et al. (2012), in which integrative and instrumental motivation correlates and both motivate students to learn a foreign language. The findings also contradicts the findings of Abdulrasoul (2012), which indicated that EFL learners from Iraq were motivated more integratively as compared to instrumentally. The responses from the learners revealed that they only need the language so that they can pass their exams and complete their assignments. On the other hand, the students didn't focus on the significance of using the language so that they can communicate perfectly with foreigners. Although, a small portion of the students reported that they were interestedin learning the target language so as they can know and understand other people's language. This indicates that they have the desire to use the English language for communicating with foreigners. This supports the findings of Gardner (2007) and Bao et al. (2012).

Based on the activities that the students preferred, it was evident that most learners loved to listen and copy notes from the board. Most of them also choose reading as the preferred activity in English learning. This finding indicates that the learners were not interested in speaking in English because they concentrated on reading and listening in their learning process. It was observed that they gave fewer efforts on activities such as playing games, doing a practice of speaking in the target language, and making summaries. This reveals that they are not interested to learn and use the English language to interact or communicate with foreigners.

\section{Conclusion and Suggestion}

This study aimed to identify the motivation of learners towards learning the English language and the activities they prefer to use in the learning process. Based on the findings of this research study, it is concluded that most of the learners from the sampled universities in Iraq were motivated instrumentally to learn English. However, a small percentage of the learners were motivated integratively. This shows that most learners were not interested to learn and use English to communicate with foreigners but rather just to do their assignments and pass 
exams. Accordingly, the activities the learners preferred to learn English were not important since the students concentrated only on those that were related to reading and writing and showed less interest in activities related to speaking. This could be attributed to their (instrumental) nature of motivation.

The study suggests that School administrators should come up with seminars that will teach teachers on how to apply effective activities to enhance English teaching and learning processes and other methodologies in teaching English subjects. English teachers are also supposed to look at their current methods of teaching and if they are not effective they need to incorporate effective type of motivation in their teaching. More studies should be conducted to investigate the appropriate type of activity that learners mostly like to practice in classroom.

\section{Conflict of Interest}

The authors declare no conflict of interest.

\section{Funding}

The study was not funded by any institution/ university.

\section{References}

Abdulrasoul, I. A. (2012). Analyzing the Motivation of Iraqi Students for Joining Departments of English. Proceeding of the 1st conference at Kerbala University. Kerbala University: Al-Bahith Journal, 3(5), 607-625.

Albodakh, M. \& Cinkara, E. (2017). The relationship between learner motivation and Vocabulary Size: The Case of Iraqi EFL Classrooms. Arab World English Journal, 8(2), 279-292. DOI: 10.24093/awej/vol8no2.20

Al-Tamimi, A. \& Shuib, M. (2009). Motivation and attitudes towards learning English: A study of petroleum engineering undergraduates at Hadhramount University of Sciences and Technology. Online Journal of Language Studies, 9(2), 29-55.

Bao, D., Abdilah, H. \& Chowdhury, R. (2012). EFL learners moving to an ESL context:

Motivating and demotivating factors in English language learning among Iraqis. The New English Teacher, 6(1), 125-144.

Binalet, C., \& Guerra, J. (2014). A Study on the Relationship between Motivation and LanguageLearning Achievement among Tertiary Students. International Journal of Applied Linguistics and English Literature, 3(5), 251-260.

Brown, H. D. (1994). Principles of Language Learning And Teaching (3rd ed.). New Jersey: Prentice-Hall Regents, Englewood Cliffs 
Carreira, J. (2005). New framework of intrinsic/ extrinsic and integrative/instrumental motivation in second language acquisition. The Keiai Journal of International Studies, $16,39-64$.

Ellis, R. (1994). The Study of Second Language Acquisition. Oxford: Oxford University Press.

Gardner, R. C. (2007). Motivation and Second Language Acquisition. Porta Linguarum, 8, 9 20.

Gardner, R. \& Lambert, W. (1959). Motivational variables in second-language acquisition. Canadian Journal of Psychology/Revue canadienne de psychologie, 13(4), 266-272.

Horwitz, E. (1990). Attending to the affective domain in the foreign language classroom: Shifting the instructional focus to the learner. Middlebury, VT: Northeast Conference of foreign language teachers.

Hussein, S. B. \& Al Bajalani, F. R. (2019). The role of motivation in developing autonomy among university EFL students in the Kurdistan Region of Iraq: Students' Attitudes. Journal of Garmian University, 6(1), 277-296. DOI: 10.24271/garmian.616

Kumar, M. (2005). Modern teaching of educational psychology. Anmol Publications Pvt Ltd.

Lambert, W. (1963). Psychological approaches to the study of language. Part II: On the second language learning and bilingualism. The Modern Language Journal, 47(3), 114-121.

Mohd Redzuan, N., Buda, A., \& Abdullah, N. (2014). English language learning: A survey of motivation and preferred activities among engineering students in Polytechnic Kuching Sarawak. Journal of Techno Social, 5(2), 78-87.

Qin, X. (2012). A comparative study of activity preferences of learners and teachers in college English Teaching and Its Implications for Curriculum Design. International Journal of English Linguistics, 2(6), 40-49.

Wimolmas, R. (2013). A survey study of motivation in English language learning of firstyear undergraduate students at Sirindhorn International Institute of Technology (SIIT), Thammasat University. Proceedings of the 3rd International Conference on Foreign Language Learning and Teaching 2013 (FLLT 2013), "Research, Renovation and Reinforcement: Enhancing Quality in Language Education", Bangkok, Thailand. 